\title{
Recent trends in Gender Mainstreaming and Poverty Alleviation: The Kudumbashree Initiative
}

\author{
Nupur Tiwari ${ }^{1}$ \\ Centre for Federal Studies \\ Jamia Hamdard University \\ New Delhi
}

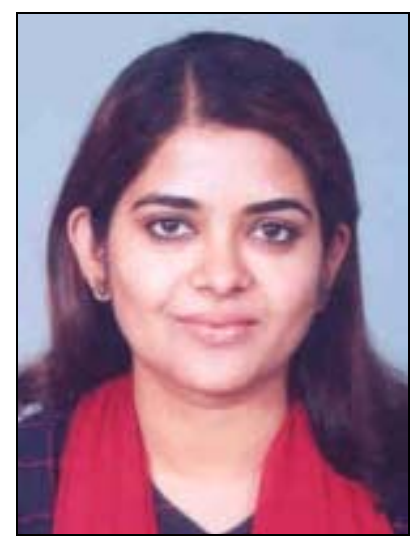

Kudumbashree was officially launched in 1998 in the State of Kerala, India, with the objective of eradicating absolute poverty in 10 years through community action. It is a comprehensive women-based poverty eradication programme jointly initiated by Government of Kerala and National Bank for Agriculture and Rural Development (NABARD), scaled up from earlier UNICEF-assisted initiatives in Alappuzha Municipality and Malappuram district. The programme is implemented by community-based organizations (CBOs) of poor women in co-operation with local governments (Panchayats).

Kudumbashree focuses on empowerment of women through its CBOs and activities such as service coordination, encouraging thrift and internal lending, and start-up of micro enterprises. There are success stories of enterprises such as catering and canteen services at

\footnotetext{
${ }^{1}$ The views expressed in this practice note are those of the author and do not necessarily reflect any official policy or position on the issues discussed.
} 
bus stands and offices in several places across the state. Handling of solid waste in municipalities is another emerging area of activity.

Kudumbashree is not a commercial-type microfinance organization. In contrast to the income poverty approach of the Government of India, KDS has developed a more comprehensive (holistic) approach to poverty identification. It targets the overall development of women and children from families below the poverty line (BPL). Importance is given to healthy nutrition, education, employment, and improvement of economic status, which are related to the risk factors and the social environment of an individual or family. Hence, it sets the following criteria for identifying poor families:

- Whether the family lives in a Kutcha House ${ }^{2}$

- Whether it has access to safe drinking water

- Whether it has access to a sanitary latrine

- Whether the family is barely getting two meals a day or less

- Whether any adult in the family is illiterate

- Whether anyone in the family is alcoholic or drug addicted

- Whether the family has no income-earning member or just one

- Whether there are children below the age of 5 in the family.

A family which fulfills four of the above criteria is identified as a poor family and becomes a member of a Kudumbashree neighbourhood group.

A key feature of Kudumbashree is that groups have prospered under the benefaction and leadership of Local Self Governments and have participated in the programmes of Panchayats, while other similar groups operate separately from local government.

Kudumbashree neighbourhood groups (NHGs) consist of one adult woman from each of 1540 families at risk. At the Panchayat ward level, 10-15 NHGs are federated into an Area Development Society (ADSs), while at the Gram Panchayat (local government area) level,

\footnotetext{
${ }^{2}$ A temporary structure made of crude materials such as mud-clay, un-burnt bricks, bamboos, grass, reeds, thatch or loosely packed stones is referred to as a Kutcha house.
} 
the ADSs are federated into Community Development Societies (CDSs). As of now there are 162,619 NHGs (covering nearly 3 million families) 14,245 ADSs, and 1,050 CDSs across the state.

The NHGs become Thrift and Credit Societies (TCSs) and their basic function is to mobilize the poor to make small savings. These savings are deposited in a commercial/cooperative bank and are used to provide loans among members. The women take on the multiple roles of savers, borrowers, account-keepers and finance managers. Also, the NHGs identify destitute families and the Panchayats provide a package of care services.

Kudumbashree was launched as part of the ninth five-year plan (1997 to 2002). An integrated approach to poverty reduction was urgently required as the most marginalized section of society, the poorest of the poor, were still not getting the benefits from the anti poverty projects of local governments. So a decision was taken to introduce a communitybased approach to participatory micro-level planning in all local governments. Thus from modest beginnings this initiative has now been extended throughout the state. There is now a clear structure for anti-poverty planning with Kudumbashree groups identifying destitutes and participating in plan preparation and implementation by Panchayats.

Among the significant works taken by Kudumbashree, some deserve special mention:

- Ashraya: The first role of this programme is to identify destitutes and find out the various deprivations that they face in terms of food, health (chronic illness, fatal diseases), pensions, education, drinking water, sanitation, employment, skills development and so on. The mission ${ }^{3}$ addresses these deprivations and tries to rehabilitate them.

- Balasabha: This is a grassroots children's group for BPL families. The mission identifies these children and provides a supportive environment for informal education.

- Bhavanshree: This is a micro housing programme catering to the housing needs of BPL families, planned by Kudumbashree.

\footnotetext{
${ }^{3}$ State Poverty Eradication mission - Government of Kerala
} 
- Yatrashree: This programme aims at setting up a chain of hotels along the wayside of major roads of the state.

- Vidyashree: This programme provides computers for high schools to teach computer literacy in 14 districts across the state.

- Kerashree: This programme produces and looks into the marketing of branded coconut oil

- Harithashree: This programme identifies leasehold land and provides it to poor families who are ready to do farming, but do not have the land.

- S3 Panchayats: The focus of this programme is implementation of a developmental model of 'Sustainability, Self-reliance and Self-sufficiency' (S3) in selected Panchayats.

- Clean Kerala: Under this programme groups of women have been established to undertake collection and transporting of solid waste from households, marketplaces, hotels etc.

\section{Empowerment of Women}

Empowerment can be seen as a concept where the people achieve greater control over decision-making and resources, and where they acquire increased social mobility and dignity. In this context, women have made good progress in planning projects, collective bargaining, the ability to address a group, and improvements in overall skills and capabilities. Progress has also been made in generating awareness of their rights and forms of discrimination, and enhancing self confidence. Their social status has also risen among their family members and social circle.

Amartya Sen identified 'bargaining' as an important non-material capability in determining outcomes, and the ability to collectively bargain, plan projects and organize group activities has been greatly improved through the Kudumbashree movement.

Hence social capital has been considerably enhanced. There is much more willingness to cooperate with others, leading to mutual trust, and the trust of the community in the members 
of SHGs has also increased. Cooperation with representatives of local government has also improved significantly. Kudumbashree thus combines credit support with social capital.

\section{Poverty Alleviation}

Kudumbashree has registered a spectacular growth in the number of families covered. The number of NHGs increased from 37,000 in April 2000 to over 160,000 today. The number of poor families (identified using the criteria outlined earlier) as per official records is heading towards 3.8 million in a state with around 7.5 million households.

Due to the programme Bhavanshree there is reported improvement in housing, but the full impact of Bhavanshree and other housing related schemes will take some time. Evident progress has also been made with regards to sanitary facilities, employment (especially selfemployment), nutrition (the proportion of the families taking traditional three meals a day), and reduced alcoholism. There is also improvement in the capacity to borrow for a majority of the poor.

\section{Some Issues}

However, Kudumbashree does face some significant issues. The first of these is competing programmes. Other NGOs have also organized self-help groups that offer micro credit, mobilize savings and provide a connection to banking services. These parallel organizations could create serious difficulties for Kudumbashree, which currently enjoys a respected place as a microfinance institution.

Second, overloading the people involved in Kudumbashree may also become a problem, as the programme is engaged in such a wide range of activities.

Third, whilst creating more micro enterprises is seen as the chief instrument for generating employment and income for women, it is important that effort also goes into steadily improving the quality of those enterprises, encouraging new approaches and introduction of new technologies. 
Fourth, there are issues with the interface between Kudumbashree and local governments. Kudumbashree members are prominent in the Gram Sabha (a biannual meeting of all eligible voters in a village), and this is seen as an important way of empowering women and achieving the necessary quorum for meetings. Also, it is a way of influencing the Panchayats' Women's Component Plans and thereby generating a substantial source of funds for Kudumbashree programmes. However, the quality of participation is questionable, and Kudumbashree is not directly engaged in strengthening local governments.

On the other hand, indirectly Kudumbashree is supporting the socio-political process of decentralization in Kerala as many leaders of the Kudumbashree movement are getting elected to Panchayat committees. Also, Kudumbashree groups involved in agricultural production have cooperated with the Panchayats in plan formulation and implementation of various activities like watershed development and organic farming.

\section{Conclusion}

In spite of some issues and potential difficulties, the Kudumbashree movement has certainly helped in both gender mainstreaming and poverty alleviation. It has firstly made women more aware of the causes of poverty and the ways to resolve it. Financial security is the prerequisite for any empowerment and the Kudumbashree movement has helped women to stand on their own feet by giving them greater economic self- reliance through establishment of micro-enterprises and other income generating activities. Women share and discuss issues affecting their sources of income and livelihoods in the weekly meetings of NHGs.

The Kudumbashree network also ensures that women are actively involved in planning and development processes as they take part in preparing micro-plans at the NHGs level and higher level plans through both ADSs and CDSs, which are then integrated into the poverty eradication plans of local governments. This combination of hard work, joint action, inventiveness, planning and active participation in local governance is the key to success. 


\section{References:}

Balan, P P \& Retna Raj M (eds.) 2006, Decentralised Governance and Poverty Reduction: Lessons from Kerala, Kerala Institute of Local Administration, Trissur.

Heeks, R \& Arun, S 2007, 'IT Social Outsourcing as a Development Tool: IT Outsourcing to Social Enterprises for Poverty Reduction and Women's Empowerment in Kerala', Development Informatic Group, IDPM, University of Manchester, Manchester.

Kerala Institute of Local Administration (KILA) 2009, Report of the Committee for Evaluation of Decentralised Planning and Development March 2009, Government of Kerala, India.

Oommen, M A, 2008, 'Microfinance and Poverty Eradication: The Case Study of Kerala's Kudumbashree’, Centre for Socio-economic \& Environmental Studies (CSES), Kerala, accessed 29 November 2009, <http://csesindia.org/admin/modules/cms/docs/publication/17.pdf $>$.

Prasad, P N \& Sreedevi, V 2007, 'Economic Empowerment of Women through Information Technology': A Case Study from an Indian State', Journal of International Women's Studies, 2007 May; 8(4), pp. 107-120.

Ramanathan, R 2008, 'Federalism, Urban Decentralisation and Citizen Participation’ in Kadekodi G K, Kanbur R, Rao V, Developments in Karnataka: Challenges of Governance, Equity and Empowerment, Academic Foundation, New Delhi, pp. 219 242.

Ministry of Panchayati Raj 2006, Report on the State of the Panchayats: A Mid-Term Review and Appraisal 22 November, 2006 (Vol.I, Vol.II and Vol.III), Government of India, New Delhi.

Vijayanand S M 2006, “A Programme for Community-Based Social Security Through Panchayati Raj Institutions”, Asraya, Kerala, India. 
Appendix 1: Status Report of NHGs and Thrift \& Credit under Kudumbashree

\begin{tabular}{|c|c|c|c|c|c|c|c|c|c|}
\hline No & District & $\begin{array}{l}\text { No. of } \\
\text { GPs }\end{array}$ & $\begin{array}{l}\text { No. of } \\
\text { NHG }\end{array}$ & $\begin{array}{l}\text { No. of } \\
\text { ADS }\end{array}$ & $\begin{array}{l}\text { Families } \\
\text { Covered }\end{array}$ & $\begin{array}{c}\text { Families } \\
\text { Started } \\
\text { Thrift }\end{array}$ & $\begin{array}{c}\text { Thrift (In } \\
\text { crores) }\end{array}$ & $\begin{array}{c}\text { Loan (In } \\
\text { crores) }\end{array}$ & VIL \\
\hline & Rural (14 districts) & & & & & & & & \\
\hline 1 & Thiruvanathapuram & 78 & 16744 & 1259 & 344225 & 341807 & 101 & 222 & 2.21 \\
\hline 2 & Kollam & 71 & 12174 & 1214 & 223550 & 223550 & 70 & 156 & 2.24 \\
\hline 3 & Pathanamthitta & 54 & 6602 & 744 & 136670 & 136405 & 49 & 63 & 1.3 \\
\hline 4 & Alappuzha & 73 & 13348 & 1106 & 263218 & 263218 & 81 & 181 & 2.25 \\
\hline 5 & Kottayam & 75 & 11039 & 1153 & 222784 & 222762 & 56 & 107 & 1.92 \\
\hline 6 & Idukki & 52 & 9160 & 750 & 166607 & 166094 & 66 & 157 & 2.36 \\
\hline 7 & Ernakulam & 88 & 12966 & 1352 & 213449 & 213078 & 67 & 229 & 3.41 \\
\hline 8 & Thrissur & 92 & 15631 & 1324 & 284239 & 284239 & 90 & 33 & 3.68 \\
\hline 9 & Palakkad & 91 & 20056 & 1436 & 340023 & 340023 & 103 & 277 & 2.7 \\
\hline 10 & Malappuram & 102 & 14676 & 1845 & 332367 & 332367 & 89 & 124 & 1.39 \\
\hline 11 & Kozhikkode & 78 & 14394 & 1309 & 295698 & 294201 & 104 & 273 & 2.62 \\
\hline 12 & Wayanad & 25 & 7314 & 434 & 120248 & 120248 & 33 & 160 & 4.86 \\
\hline 13 & Kannur & 81 & 11045 & 1264 & 209603 & 209603 & 65 & 204 & 3.14 \\
\hline \multirow[t]{2}{*}{14} & Kasargode & 39 & 5615 & 646 & 118995 & 119419 & 36 & 148 & 4.05 \\
\hline & Total & 999 & 170764 & 15866 & 3271676 & 3267014 & 1010 & 2634 & 2.61 \\
\hline 15 & Urban (58 ULBs) & & 13587 & 1134 & 347996 & 347996 & 59 & 68 & 1.16 \\
\hline \multirow[t]{2}{*}{16} & Tribal NHGs(9 Dist) & & 2339 & & 40211 & 38025 & 6 & 12 & 2.04 \\
\hline & Grand Total & & 186690 & 17000 & 3659883 & 3653035 & 1074 & 2715 & 2.53 \\
\hline
\end{tabular}

As of June 2008

Source: Govt. of Kerala - State Poverty Eradication Mission, Kudumbashree Achievements in the Field (Updated 2008 March 30) - Thrift \& Credit operations 